\title{
Amorphous aggregation of tau in the presence of titanium dioxide nanoparticles: biophysical, computational, and cellular studies
}

This article was published in the following Dove Medical Press journal: International Journal of Nanomedicine

\author{
Aida Fardanesh',* \\ Sedigheh Zibaie ${ }^{1, *}$ \\ Behdad Shariati' \\ Farnoosh Attar ${ }^{2}$ \\ Fatemeh Rouhollah' \\ Keivan Akhtari ${ }^{3}$ \\ Koroosh Shahpasand ${ }^{4}$ \\ Ali Akbar Saboury ${ }^{5}$ \\ Mojtaba Falahati ${ }^{6}$ \\ 'Department of Cellular and \\ Molecular Biology, Faculty of \\ Advanced Science and Technology, \\ Tehran Medical Sciences, Islamic \\ Azad University, Tehran, Iran; \\ ${ }^{2}$ Department of Biology, Faculty \\ of Food Industry and Agriculture, \\ Standard Research Institute (SRI), \\ Karaj, Iran; ${ }^{3}$ Department of Physics, \\ University of Kurdistan, Sanandaj, Iran; \\ ${ }^{4}$ Department of Brain and Cognitive \\ Sciences, Cell Science Research \\ Center, Royan Institute for Stem \\ Cell Biology and Technology, ACECR, \\ Tehran, Iran; ${ }^{5}$ Institute of Biochemistry \\ and Biophysics, University of \\ Tehran, Tehran, Iran; ${ }^{6}$ Department \\ of Nanotechnology, Faculty of \\ Advanced Science and Technology, \\ Tehran Medical Sciences, Islamic Azad \\ University, Tehran, Iran \\ *These authors contributed equally \\ to this work
}

Correspondence: Mojtaba Falahati Department of Nanotechnology, Faculty of Advanced Science and Technology, Tehran Medical Sciences, Islamic Azad University, Tehran, Iran Email mojtaba.falahati@alumni.ut.ac.ir
Background: Nanoparticles (NPs) when injected into the body can reach target tissues like nervous system and interact with tau proteins and neurons. This can trigger conformational changes of tau and may affect NP toxicity.

Methods: In this study, we used several biophysical techniques (extrinsic and intrinsic fluorescence spectroscopy, circular dichroism (CD) spectroscopy, ultraviolet (UV)-visible spectroscopy), transmission electron microscopy (TEM) investigations, molecular docking and molecular dynamics studies, and cellular assays [3-(4,5-Dimethylthiazol-2-Y1)-2,5-Diphenyltetrazolium Bromide (MTT) and flow cytometry) to reveal how structural changes of tau protein can change the cytotoxicity of titanium dioxide $\left(\mathrm{TiO}_{2}\right)$ NPs against neuron-like cells (SH-SY5Y) cells.

Results: It was shown that $\mathrm{TiO}_{2} \mathrm{NPs}$ result in hydrophilic interactions, secondary and tertiary structural changes, and the formation of amorphous tau aggregates. Conformational changes of tau increased the induced cytotoxicity by $\mathrm{TiO}_{2} \mathrm{NPs}$. These data revealed that the denatured adsorbed protein on the NP surface may enhance NP cytotoxicity.

Conclusion: Therefore, this study provides useful insights on the NP-protein interactions and discusses how the protein corona can increase cytotoxicity to determine the efficacy of targeted delivery of nanosystems.

Keywords: titanium oxide nanoparticle, tau, amorphous aggregation, cytotoxicity, neuronlike cells

\section{Introduction}

Advancements in nanobiotechnology have resulted in the progress of a new area of nanomedicine, which incorporates the implementation of nanomaterials in diagnostic, ${ }^{1}$ imaging, ${ }^{2}$ and therapeutic settings. ${ }^{3}$ Although, nano-based agents are presently being extensively utilized in biological and medicinal approaches, there is a momentous concern regarding human ${ }^{4}$ and environmental risk $^{5}$ upon implications of fabricated nanomaterials. Recent in vivo ${ }^{6}$ and in vitro ${ }^{6,7}$ investigations have suggested that utilization of some nanoparticles (NPs) may induce serious toxic health impacts and the application of nanomaterials-based medical agents may result in chronic or acute health problems. ${ }^{8}$ Thus, along with the development of unique NPs, simultaneous investigation of the impacts of NPs on the biological systems should be carried out. Once NPs interact with a biological system, they are exposed to corona formation around them. The biological responses of NPs coated with protein corona are totally different compared to bare NPs. ${ }^{9}$ The first investigation on the interactions between NPs and proteins was carried out in $1996 .{ }^{10}$ Studies are now based on NP-protein corona complexes as the working NPs in the biological fluids. ${ }^{9}$ During the interaction of 
NPs and biomolecules, proteins are subjected to pronounced alterations in their structure and may change the fate of NPs. ${ }^{9}$ Therefore, characterization of the proteins in the presence of NPs and cytotoxicity of NP-protein corona complexes have become crucial in experimental settings involving the application of NPs. Several studies have been recently devoted to extrapolate general rules to investigate the biological effect of the NP-protein corona on human cells. ${ }^{11-13}$

Among different fabricated metal oxide NPs, titanium dioxide $\left(\mathrm{TiO}_{2}\right)$ NPs have been extensively utilized for biological and medical applications like cancer ablation ${ }^{14-17}$ and as antibacterial agents. ${ }^{18}$ However, the fundamental demands for the potential application of NPs in biomedical settings include their good colloidal stability, marginal structural changes of protein coronas, and low adverse effects.

Application of NPs results in their interaction with tissues components like the nervous system and inducing tau aggregation and neuronal death accompanied by neurodegenerative diseases. The two major neurodegenerative diseases affecting the world population include Alzheimer and Parkinson: the major tauopathies and alpha-synucleopathies, respectively. Alzheimer's disease has been described in populations highly exposed to NPs. In children and young adults, NPs are found to be associated with major abnormalities in subcellular organelles. ${ }^{19-21}$

Therefore, studies should be oriented toward investigating the interaction of $\mathrm{TiO}_{2} \mathrm{NPs}_{\mathrm{s}}$ with some biological systems such as the nervous system. Here, we tried to explore the interaction of $\mathrm{TiO}_{2}$ NPs with tau and the cytotoxicity of $\mathrm{TiO}_{2} \mathrm{NPs} /$ tau complex against SH-SY5Y as models of nervous systems in vitro by biophysical, bioinformatic, and cellular assays.

\section{Materials and methods Materials}

Tau-441 human recombinant, expressed in Escherichia coli, thioflavin T (ThT), Nile red, 8-anilinonaphthalene-1-sulfonic acid(ANS), DMEM and Ham's F-12 nutrient mixture (DMEMF12), FBS, penicillin, and streptomycin were purchased from Sigma-Aldrich Co (St Louis, MO, USA). The SH-SY5Y human neuroblastoma cell line was purchased from Pasteur Institute, Tehran, Iran. All other chemicals were of reagent grade.

\section{Sample preparation}

Tau solution was prepared in phosphate buffer, with $\mathrm{pH} 7.4$ and ionic strength of $10 \mathrm{mM}$. Tau concentration was estimated spectrophotometrically at $280 \mathrm{~nm}$, using an extinction coefficient of $7,450 \mathrm{~cm}^{-1} \mathrm{~m}^{-1}$. Stock solution of $\mathrm{TiO}_{2} \mathrm{NP}$ was freshly prepared at $10 \mathrm{mg} / \mathrm{mL}$, using ethanol $(0.5 \%)$ as a solvent.

\section{Tryptophan fluorescence assay}

Aliquots of the tau solutions $(0.1 \mu \mathrm{g} / \mathrm{mL})$ were incubated without or with different concentrations of $\mathrm{TiO}_{2} \mathrm{NPs}(0.5,1,5$, $10,20,30$, and $40 \mu \mathrm{g} / \mathrm{mL}$ ) for 2 minutes. Fluorescence assays were then carried out by a Cary Eclipse VARIAN fluorescence spectrophotometer (Agilent, Mulgrave, VIC, Australia). Samples were excited at $270 \mathrm{~nm}$, and the band intensity was determined between 275 and $400 \mathrm{~nm}$, with 10-nm slit width for both excitation and emission wavelengths.

\section{ANS fluorescence assay}

The tertiary structural changes of tau were revealed by changes in the ANS fluorescence intensity of a mixture with $0.1 \mu \mathrm{g} / \mathrm{mL}$ tau solutions and $10 \mu \mathrm{M}$ ANS in the absence and presence of varying concentrations of $\mathrm{TiO}_{2} \mathrm{NPs}(0.5,1,5,10$, 20,30 , and $40 \mu \mathrm{g} / \mathrm{mL}$ ) with the excitation wavelength fixed at $350 \mathrm{~nm}$. Excitation and emission slit widths were both set to $5 \mathrm{~nm}$. ANS fluorescence measurement was corrected against buffer and NP solutions.

\section{ThT fluorescence assay}

The formation of tau fibrils was detected by changes in the ThT fluorescence intensity of a mixture including $0.1 \mu \mathrm{g} / \mathrm{mL}$ tau solutions and $10 \mu \mathrm{M}$ ThT in the presence of varying concentrations of $\mathrm{TiO}_{2}$ NPs $(0.5,1,5,10,20,30$, and $40 \mu \mathrm{g} / \mathrm{mL}$ ). The excitation and emission wavelengths were set to 440 and $485 \mathrm{~nm}$, respectively. The other fluorescence spectroscopy parameters were similar with the ANS and tryptophan fluorescence assay sections.

\section{Ultraviolet (UV)-visible assay}

Tau solution $(0.5 \mu \mathrm{g} / \mathrm{mL})$ was incubated with various concentrations of $\mathrm{TiO}_{2} \mathrm{NPs}(0.5,1,5,10,20,30$, and $40 \mu \mathrm{g} / \mathrm{mL}$ ). After 2 minutes of incubation at room temperature, absorbance spectra were read at $360 \mathrm{~nm}$. UV-visible assays were performed by a Cary Eclipse VARIAN spectrophotometer. In this assay, the NP absorbance was subtracted from the protein signal and the calculated absorbance was also corrected against dilution.

\section{Far-UV circular dichroism (CD) measurement}

CD spectra of tau samples $(0.2 \mu \mathrm{g} / \mathrm{mL})$ in the absence and presence of the highest studied concentration of $\mathrm{TiO}_{2} \mathrm{NPs}$ (40 $\mu \mathrm{g} / \mathrm{mL})$ were recorded by an Aviv 215 spectropolarimeter (Aviv Biomedical Inc, Lakewood, NJ, USA). After 2 minutes of incubation, the spectra were recorded in the range of 190-260 $\mathrm{nm}$. The NP ellipticity was subtracted from 
the protein ellipticity and the calculated ellipticity was also corrected against dilution.

\section{Transmission electron microscopy (TEM) analysis}

Tau solution with a concentration of $2 \mu \mathrm{M}$ was incubated with the highest studied concentration of $\mathrm{TiO}_{2} \mathrm{NPs}(40 \mu \mathrm{g} / \mathrm{mL})$. After 2 minutes of incubation, the sample was prepared for TEM analysis. The morphology of the aggregated species was then determined using a TEM microscope (EM10C100 KV; Carl Zeiss Meditec AG, Jena, Germany).

\section{Computational study}

$\left(\mathrm{TiO}_{2}\right)_{22}$ and $\left(\mathrm{TiO}_{2}\right)_{38}$ clusters were optimized as models of $\mathrm{TiO}_{2}$ NPs. The Cartesian coordinate of atoms was obtained from the study of Auvinen et al. ${ }^{22}$ HEX 6.3 software (http://hex.loria.fr/dist63/) was used to run the molecular docking study. ${ }^{23}$ The molecular dynamics simulations were performed using the Forcite code and universal force field..$^{24}$

\section{Viability assay}

SH-SY5Y cells were cultured in DMEM-F12 supplemented with $12 \%$ (V/V) FBS, $100 \mathrm{U} / \mathrm{mL}$ penicillin, and $100 \mathrm{mg} / \mathrm{mL}$ streptomycin and incubated at $37^{\circ} \mathrm{C}$ with $95 \%$ humidified air and $5 \% \mathrm{CO}_{2}$. The cells $\left(1 \times 10^{4}\right.$ per well $)$ were then cultured in 96-well plates, and the $\mathrm{TiO}_{2} \mathrm{NP}$-induced cell viability was calculated by the MTT assay. Briefly, after 24-hour exposure to different doses $(0.01,0.1,1,10,50$, and $100 \mu \mathrm{g} / \mathrm{mL})$ of $\mathrm{TiO}_{2}$ NPs and a single dose of $\mathrm{TiO}_{2} \mathrm{NP} /$ tau complex sample (100 $\mu \mathrm{g} / \mathrm{mL}$ ), $40 \mu \mathrm{L}$ of MTT ( $2 \mathrm{mg} / \mathrm{mL}$ in PBS) was added to each sample for 4 hours. The supernatants were then gently removed and $100 \mu \mathrm{L}$ of dimethyl sulfoxide was added to each well. The absorbance was then read at $570 \mathrm{~nm}$ using a microplate reader (model 3550; Bio-Rad Laboratories Inc, Hercules, CA, USA).

\section{Quantification of apoptosis}

Cells with a density of $3 \times 10^{5}$ cells per well were seeded into 6-well plates. Following the incubation of cells with $100 \mu \mathrm{g} / \mathrm{mL}$ of $\mathrm{TiO}_{2} \mathrm{NPs}$ and $100 \mu \mathrm{g} / \mathrm{mL}$ of $\mathrm{TiO}_{2} \mathrm{NPs}_{\mathrm{tau}}$ complex for 24 hours, the cells were washed, centrifuged $(67 \times g$ for 5 minutes), washed again, resuspended in $5 \mu \mathrm{L}$ propidium iodide and $5 \mu \mathrm{L}$ Annexin $\mathrm{V}$, and incubated for 30 minutes in the dark. The cells were then assayed by flow cytometry (BD FACSCalibur ${ }^{\mathrm{TM}}$; BD Biosciences, San Jose, CA, USA).

\section{Statistical analyses}

All assays were done in triplicate. Data are presented as mean \pm SE of three independent experiments. Statistical significance was estimated by one-way ANOVA followed by Dunnett's post hoc test. Values of $* P<0.05$ were reported to be significant.

\section{Results}

\section{Characterization of NPs}

$\mathrm{TiO}_{2}$ NPs were synthesized by the sol-gel route and were fully characterized by dynamic light scattering, TEM, and X-ray diffraction techniques. ${ }^{25}$ It was observed that fabricated $\mathrm{TiO}_{2}$ NPs have a narrow nano-sized diameter of around $30 \mathrm{~nm}$ and good colloidal stability. The X-ray diffraction pattern of the fabricated NPs also confirmed that the synthesized $\mathrm{TiO}_{2} \mathrm{NPs}$ are in the anatase phase. ${ }^{25}$

\section{Tryptophan fluorescence assay}

Intrinsic tau fluorescence originated from tyrosine residues, which can be selectively excited at $270 \mathrm{~nm} .{ }^{26}$ Changes in the emission signal of tyrosine residues are due to the protein structural changes induced by NPs influencing local microenvironment changes surrounding the indole ring. ${ }^{26}$ In this assay, the intrinsic fluorescence of tyrosine was read following excitation at $270 \mathrm{~nm}$ in the presence of increasing concentration of $\mathrm{TiO}_{2} \mathrm{NPs}$ by a spectrofluorometer. Figure 1 shows the $\mathrm{TiO}_{2} \mathrm{NPs-induced} \mathrm{fluorescence} \mathrm{quenching} \mathrm{of} \mathrm{tyrosine}$ residues after incubation with tau for 2 minutes. The effect of reducing the intensity of tyrosine emission spectra in the presence of increasing doses of $\mathrm{TiO}_{2} \mathrm{NPs}_{\mathrm{s}}$ can be deduced by the interaction of NPs/drugs with the native proteins.

Stern-Volmer equation was used to calculate the SternVolmer constant $\left(\mathrm{K}_{\mathrm{SV}}\right)$ in the presence $(\mathrm{F})$ and absence $\left(\mathrm{F}_{\mathrm{o}}\right)$ of NPs based on the following equation: ${ }^{26}$

$$
\mathrm{F}_{\mathrm{o}} / \mathrm{F}=\mathrm{K}_{\mathrm{sv}}[\mathrm{NP}]+1
$$

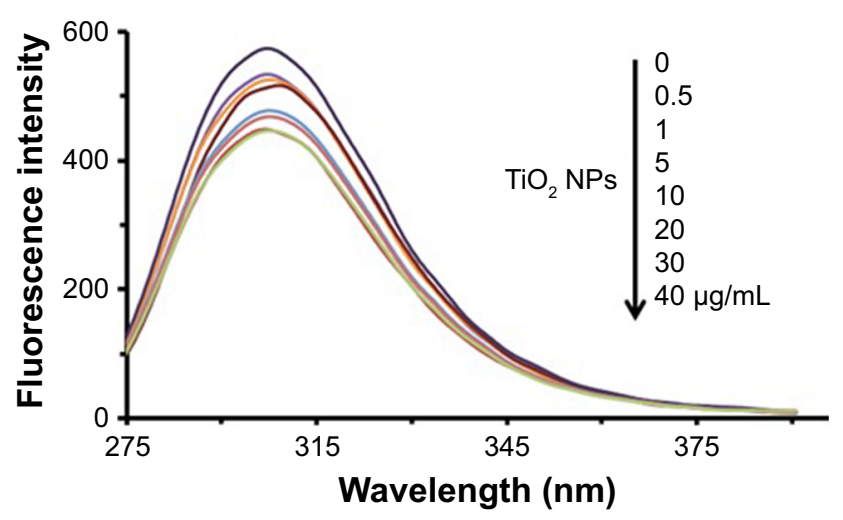

Figure I Intrinsic fluorescence quenching of tau in the absence and presence of increasing doses of $\mathrm{TiO}_{2} \mathrm{NPs}$ at room temperature.

Abbreviations: NPs, nanoparticles; $\mathrm{TiO}_{2}$, titanium dioxide. 


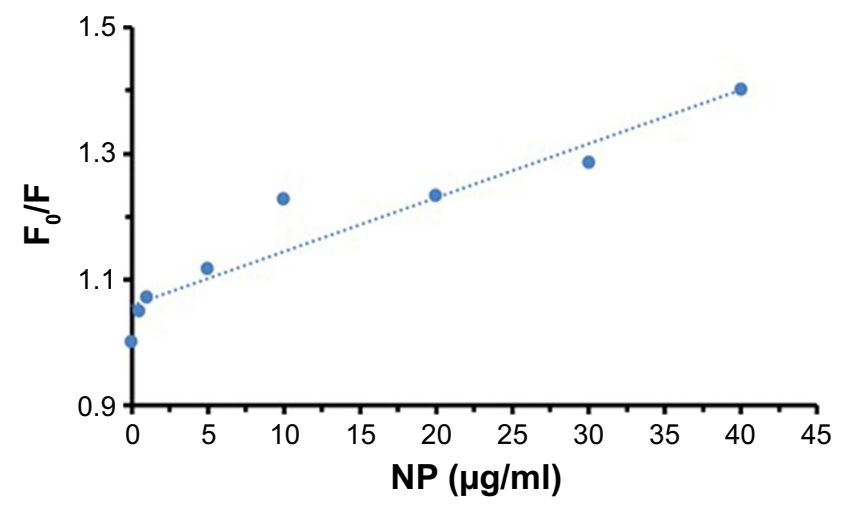

Figure 2 Stern-Volmer plot for the interaction of tau with $\mathrm{TiO}_{2} \mathrm{NPs}$. Abbreviations: NPs, nanoparticles; $\mathrm{TiO}_{2}$, titanium dioxide.

Figure 2 shows the Stern-Volmer plot for the interaction of tau with $\mathrm{TiO}_{2} \mathrm{NPs}$. The $\mathrm{K}_{\mathrm{SV}}$ value was found to be around $0.0086 \mathrm{~mL} / \mu \mathrm{g}$.

The $\mathrm{K}_{\mathrm{SV}}$ value of $\mathrm{TiO}_{2} \mathrm{NPs} /$ tau complex was compared to the $\mathrm{K}_{\mathrm{SV}}$ values of other tau complexes (Table 1). As can be seen from Table 1 , the $\mathrm{K}_{\mathrm{SV}}$ value of $\mathrm{TiO}_{2} \mathrm{NPs} /$ tau complex is lower than the $\mathrm{K}_{\mathrm{SV}}$ values of single-walled carbon nanotube/ tau and multi-walled carbon nanotube/tau complexes. ${ }^{27}$ Therefore, it may be concluded that the size, length, shape, and composition of NPs may influence the quenching parameters and kind of interaction between NPs and proteins.

\section{ANS fluorescence assay}

ANS fluorescent probe can be used to monitor the conformational changes of proteins in the presence of ligands like NPs. ${ }^{28}$ The ANS probe can bind to the hydrophobic portions of proteins by means of nonpolar-nonpolar interactions. The ANS fluorescence intensity increases sharply as hydrophobic patches of proteins are formed. The detected characteristics of ANS (Figure 3 ) in the presence of varying concentrations of $\mathrm{TiO}_{2} \mathrm{NPs}_{\mathrm{s}}$ $(0,0.5,1,5,10,20,30$, and $40 \mu \mathrm{g} / \mathrm{mL})$, a blue shift $(8 \mathrm{~nm})$ of fluorescence emission maxima and fluorescence enhancement, are mainly attributed to the conformational changes and formation of hydrophobic patches in tau structure upon NP binding.

\section{ThT fluorescence assay}

ThT fluorescence spectroscopy can be used as an important method to detect the amyloid formation of tau proteins. ${ }^{29}$
Conformational changes of proteins in the presence of ligands like NPs can result in protein aggregation. To monitor the morphology of the aggregated species of tau in the presence

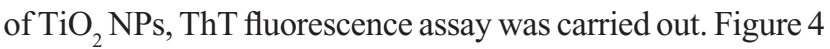
shows that by adding varying concentrations of $\mathrm{TiO}_{2} \mathrm{NPs}$, the ThT fluorescence intensities did not significantly change compared to the negative control sample. The ThT fluorescence intensities of tau samples were $19 \pm 0.63,22 \pm 0.73$, $21 \pm 0.70,23 \pm 0.76,22 \pm 0.86,24 \pm 1.14,23 \pm 1.12$, and $25 \pm 1.54$ in the presence of $0,0.5,1,5,10,20,30$, and $40 \mu \mathrm{g} / \mathrm{mL}$ of $\mathrm{TiO}_{2}$ NPs, respectively. Therefore, this assay confirms that incubation of tau protein with $\mathrm{TiO}_{2} \mathrm{NPs}_{\text {for }} 2$ minutes does not induce amyloid formation of tau proteins.

\section{UV-visible assay}

UV spectroscopy at $360 \mathrm{~nm}$ is widely used to detect the induction of protein aggregation by ligands. ${ }^{30}$ Figure 5 depicts that the absorbance of tau samples increases at $360 \mathrm{~nm}$ as the concentrations of NPs rise. The absorbance intensities of the tau sample were $0.09 \pm 0.01,0.11 \pm 0.01,0.15 \pm 0.02$, $0.19 \pm 0.03,0.27 \pm 0.03,0.33 \pm 0.03,0.42 \pm 0.05$, and $0.47 \pm 0.06$ in the presence of $0,0.5,1,5,10,20,30$, and $40 \mu \mathrm{g} / \mathrm{mL}$ of $\mathrm{TiO}_{2}$ NPs, respectively. Therefore, these data indicate the induction of tau aggregate formation by $\mathrm{TiO}_{2}$ NPs after 2 minutes of incubation.

\section{Circular dichroism assay}

We speculated that $\mathrm{TiO}_{2}$ NPs might drive early structural changes in tau to initiate subsequent aggregation. To study this hypothesis, we carried out CD spectroscopy. Figure 6 shows the CD spectra before and after incubation with $\mathrm{TiO}_{2}$ NPs for 2 minutes. It was observed that the tau structure was largely unstructured in the presence of $\mathrm{TiO}_{2}$ NPs (40 $\mu \mathrm{g} / \mathrm{mL})$ and did not adopt a random coil structure similar to the negative control tau. Therefore, it may be concluded that the natively disordered structure of tau shifted toward a more folded conformation in the presence of $\mathrm{TiO}_{2} \mathrm{NPs}$.

\section{TEM observation}

To visualize amorphous tau aggregate species, we carried out TEM on $\mathrm{TiO}_{2}$ NPs samples incubated without (Figure 7A) or

Table I $\mathrm{K}_{\mathrm{sV}}$ values of $\mathrm{TiO}_{2} \mathrm{NPs} /$ tau complex and its comparison with other reported $\mathrm{K}_{\mathrm{sV}}$ values

\begin{tabular}{l|l|l|l}
\hline Complex & $\mathbf{K}_{\text {sv }}$ value $(\mathbf{m L} / \mu \mathrm{g})$ & $\boldsymbol{R}^{2}$ & References \\
\hline $\mathrm{TiO}_{2} \mathrm{NPs} / \mathrm{tau}$ & 0.0086 & 0.91 & - \\
Single-walled carbon nanotube/tau & 7.00 & - & 27 \\
Multi-walled carbon nanotube/tau & 5.06 & - & 27 \\
\hline
\end{tabular}

Abbreviations: NPs, nanoparticles; $\mathrm{TiO}_{2}$, titanium dioxide. 


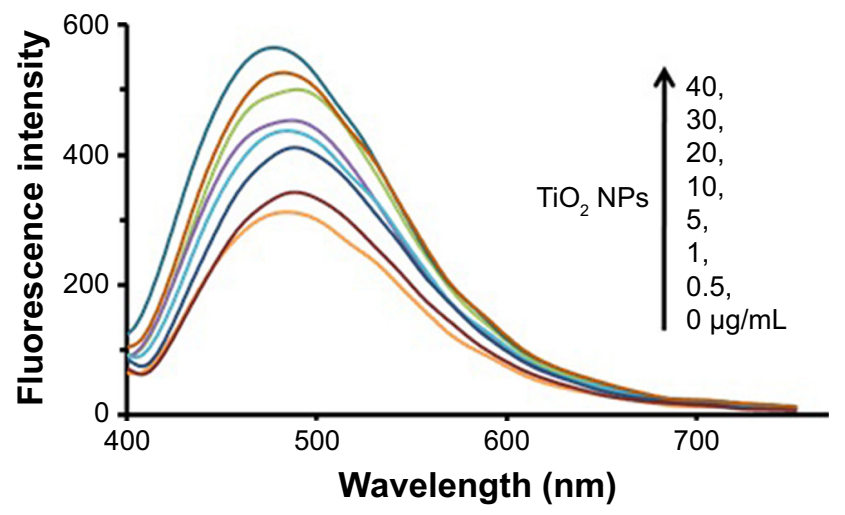

Figure 3 ANS fluorescence of tau in the absence and presence of increasing doses of $\mathrm{TiO}_{2} \mathrm{NPs}$ at room temperature.

Abbreviations: ANS, 8-anilinonaphthalene- I-sulfonic acid; NPs, nanoparticles; $\mathrm{TiO}_{2}$, titanium dioxide.

with (Figure 7B) tau. We observed that tau forms amorphous aggregates (Figure 7B) when incubated with $\mathrm{TiO}_{2} \mathrm{NPs}$. It can be concluded that incubation of tau with NPs for 2 minutes results in the formation of amorphous tau aggregates. These amorphous aggregates then should be examined to explore if they act as a nucleus to initiate the formation and elongation of amyloid aggregates over time.

\section{Molecular docking study}

Molecular docking is considered to be a leading tool in biophysical and pharmaceutical sciences..$^{31,32}$ The aim of NPprotein docking is to complete the experimental data and estimate the predominant binding site(s) of an NP to a protein. Molecular docking was performed with two clusters of $\mathrm{TiO}_{2}$ NPs with different sizes (Figure 8). The crystallographic fragments of human tau protein (PDB IDs: $2 \mathrm{MZ7}, 4 \mathrm{E} 0 \mathrm{~N}$, 5O3T) were downloaded from the online Protein Data Bank, RCSB PDB (http://www.pdb.org). Visualization of the docked sites was carried out by Chimera (www.cgl.ucsf. edu/chimera) and PyMOL (http://pymol.sourceforge.net/)

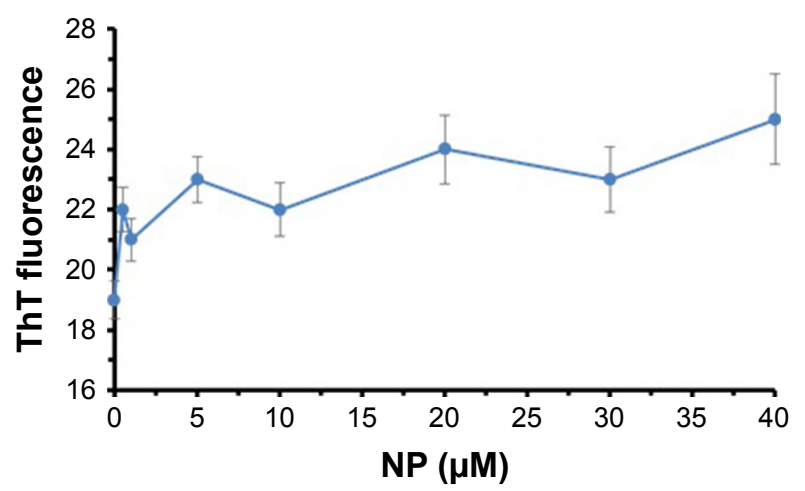

Figure $4 \mathrm{ThT}$ fluorescence intensity of tau in the absence and presence of increasing doses of $\mathrm{TiO}_{2} \mathrm{NPs}$ at room temperature.

Abbreviations: NPs, nanoparticles; ThT, thioflavin $\mathrm{T} ; \mathrm{TiO}_{2}$, titanium dioxide.

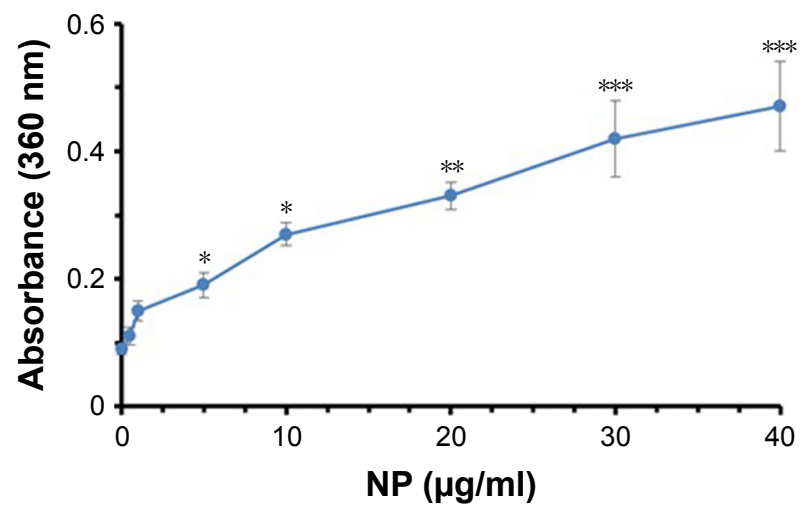

Figure 5 The absorbance intensity of tau at $360 \mathrm{~nm}$ in the absence and presence of increasing doses of $\mathrm{TiO}_{2} \mathrm{NPs}$ at room temperature.

Note: $* P<0.05, * * P<0.01$, and $* * * P<0.001$ vs control group.

Abbreviations: NPs, nanoparticles; $\mathrm{TiO}_{2}$, titanium dioxide.

tools. The docked complexes of $\left(\mathrm{TiO}_{2}\right)_{22}$ cluster-tau segments and $\left(\mathrm{TiO}_{2}\right)_{38}$-tau segments are shown in Figures 9 and 10, respectively. The $\mathrm{TiO}_{2}$ cluster with the closest residues (4 $\AA$ ) is demonstrated in Figure 11. The resulting binding energies and the interacting residues for $\left(\mathrm{TiO}_{2}\right)_{22}$ clustertau segments and $\left(\mathrm{TiO}_{2}\right)_{38}$-tau segments are summarized in Tables 2 and 3, respectively.

Data clearly indicated that the applications of different clusters with different sizes resulted in changing the binding site location on tau segments. Data also showed that the $\left(\mathrm{TiO}_{2}\right)_{38}$ cluster provides more affinity to interact with tau segments than the $\left(\mathrm{TiO}_{2}\right)_{22}$ cluster. The affinity of the larger cluster to 503 T segments (aggregated segment) was highest among other segments (with the lowest binding energy of -451.53). The important interactive residues of 5O3T segment with $\left(\mathrm{TiO}_{2}\right)_{38}$ cluster were Arg-349.J, Arg-349.H, Gln-351.J, Gln351.F, Lys-369.D, Ile-371.H, Ile-371.F, Ile-371.D, Ile-371.B, Thr-373.B, Thr-373.H, Thr-373.F, and Thr-373.D. It can be suggested that hydrophilic residues on the 5O3T segment are predominant active sites interacting with the $\left(\mathrm{TiO}_{2}\right)_{38}$ cluster.

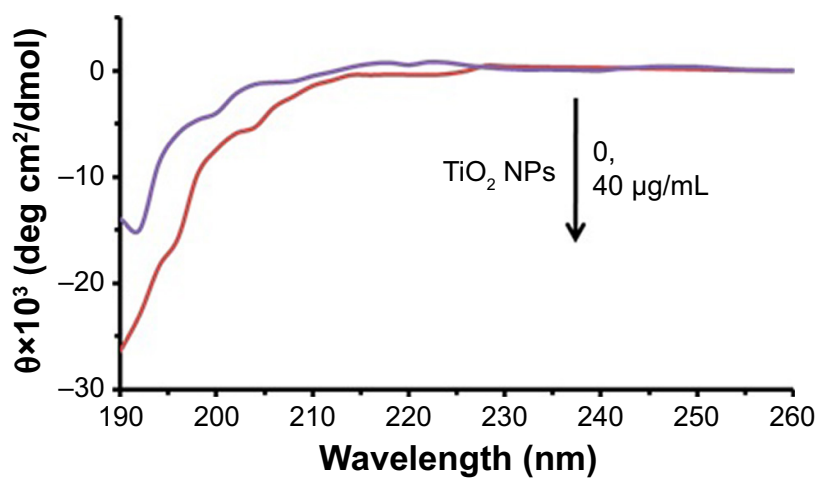

Figure $6 \mathrm{CD}$ signals of tau in the absence and presence of $\mathrm{TiO}_{2} \mathrm{NPs}$ at room temperature.

Abbreviations: NPs, nanoparticles; $\mathrm{TiO}_{2}$, titanium dioxide. 

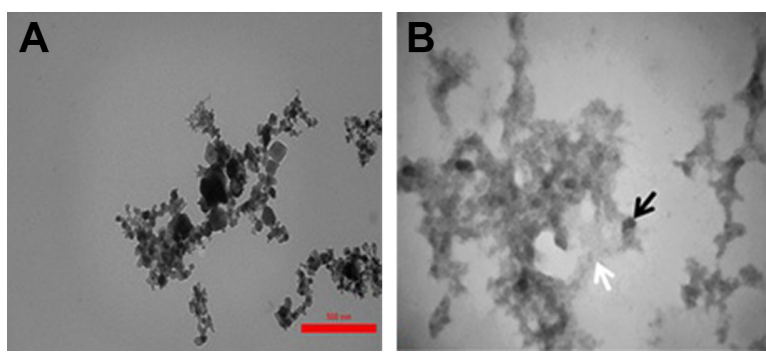

Figure 7 TEM observation of $\mathrm{TiO}_{2}$ NPs samples incubated without (A) or with (B) tau. Black and white arrows show $\mathrm{TiO}_{2} \mathrm{NPs}$ and amorphous tau aggregates, respectively.

Abbreviations: NPs, nanoparticles; TEM, transmission electron microscopy; $\mathrm{TiO}_{2}$, titanium dioxide.

\section{Molecular simulation}

For molecular dynamics simulations, the NP cluster and 2MZ7 segment were surrounded by 500 water molecules. Also, the annealing process was set to the equilibrium temperature of $298 \mathrm{~K}$. The NVE ensemble with a time step of $1 \mathrm{fs}$, and a simulation time of $300 \mathrm{ps}$, was run. The structural changes of the $2 \mathrm{MZ7}$ segment in the presence (Figure 12A) and absence (Figure 12B) of the $\mathrm{TiO}_{2} \mathrm{NP}$ cluster after $300 \mathrm{ps}$ evolution are shown in Figure 12. As shown in Figure 12, the adsorbed protein tends to shift from a disordered structure toward a more folded structure.

\section{MTT assay}

MTT assay was performed to explore the $\mathrm{TiO}_{2} \mathrm{NP}$ - and $\mathrm{TiO}_{2}$ $\mathrm{NP} /$ tau complex-induced cytotoxicity against SH-SY5Y cells. Figure 13 shows that after addition of different concentrations of $\mathrm{TiO}_{2} \mathrm{NP}$, the cell viability reduced in a dosedependent manner. In the next phase, cells were incubated with $\mathrm{TiO}_{2} \mathrm{NP}(100 \mu \mathrm{g} / \mathrm{mL}) / \mathrm{tau}(100 \mu \mathrm{g} / \mathrm{mL})$ complex for 24 hours to assess the effect of amorphous tau aggregates on the $\mathrm{TiO}_{2}$ NPs-induced cytotoxicity. As shown in Figure 13, a significant difference was observed between $\mathrm{TiO}_{2} \mathrm{NPs}$ and $\mathrm{TiO}_{2} \mathrm{NPs} /$ tau samples in the induced cytotoxicity against

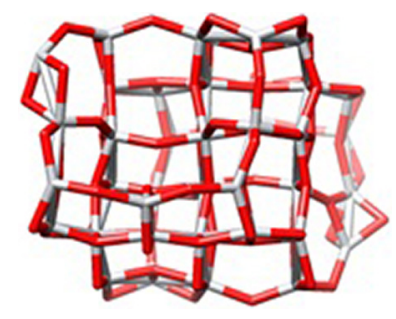

$\left(\mathrm{TiO}_{2}\right)_{38}$

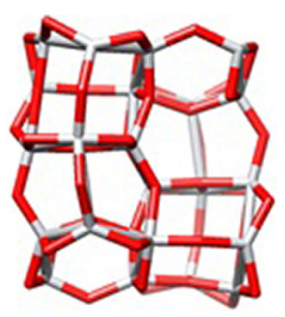

$\left(\mathrm{TiO}_{2}\right)_{22}$
Figure 8 Two clusters of $\mathrm{TiO}_{2} \mathrm{NPs}$ with different sizes. Abbreviations: NPs, nanoparticles; $\mathrm{TiO}_{2}$, titanium dioxide.
A

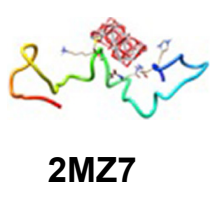

B

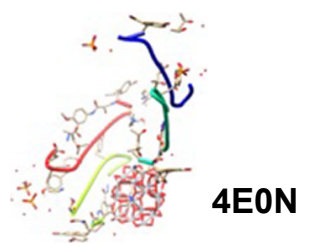

C

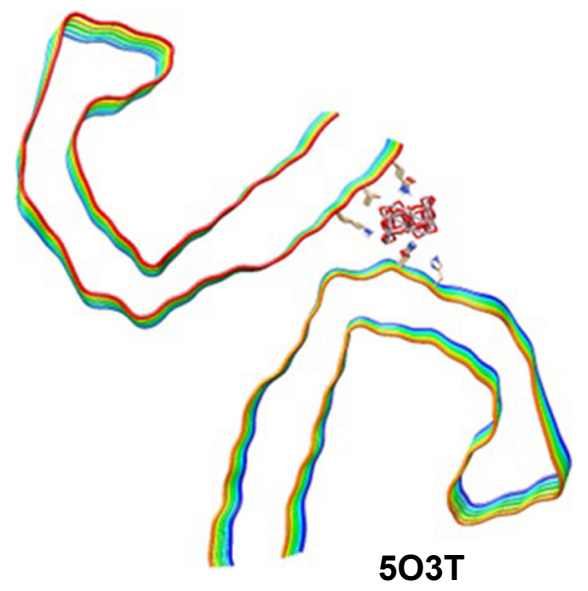

Figure 9 Docking site of interaction between $\left(\mathrm{TiO}_{2}\right)_{22}$ cluster and tau segments. Note: (A) 2MZ7, (B) 4EON, (C) 5O3T.

Abbreviation: $\mathrm{TiO}_{2}$, titanium dioxide.

SH-SY5Y cells $\left({ }^{\#} P<0.05\right)$. It can be suggested that incubation of $\mathrm{TiO}_{2} \mathrm{NPs}$ with tau and formation of amorphous tau aggregates on the NP surface may increase the induced cytotoxicity by $\mathrm{TiO}_{2} \mathrm{NPs}$.
A

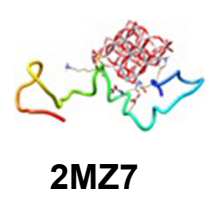

B

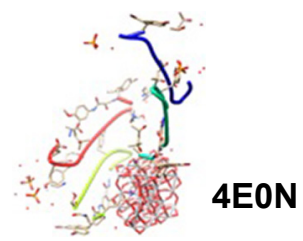

\section{C}

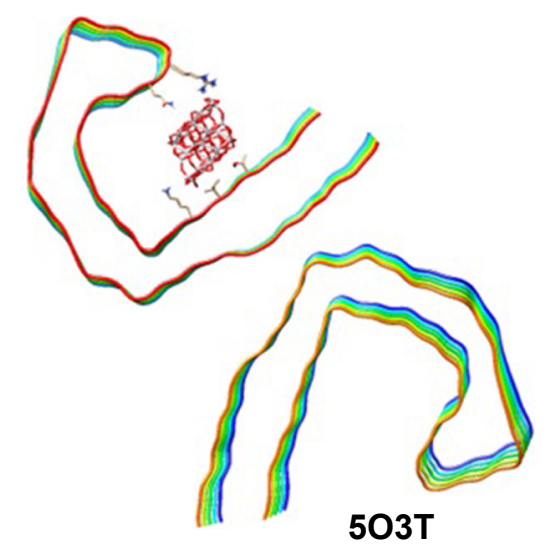

Figure 10 Docking site of interaction between $\left(\mathrm{TiO}_{2}\right)_{38}$ cluster and tau segments. Note: (A) 2MZ7, (B) 4E0N, (C) 5O3T.

Abbreviation: $\mathrm{TiO}_{2}$, titanium dioxide. 

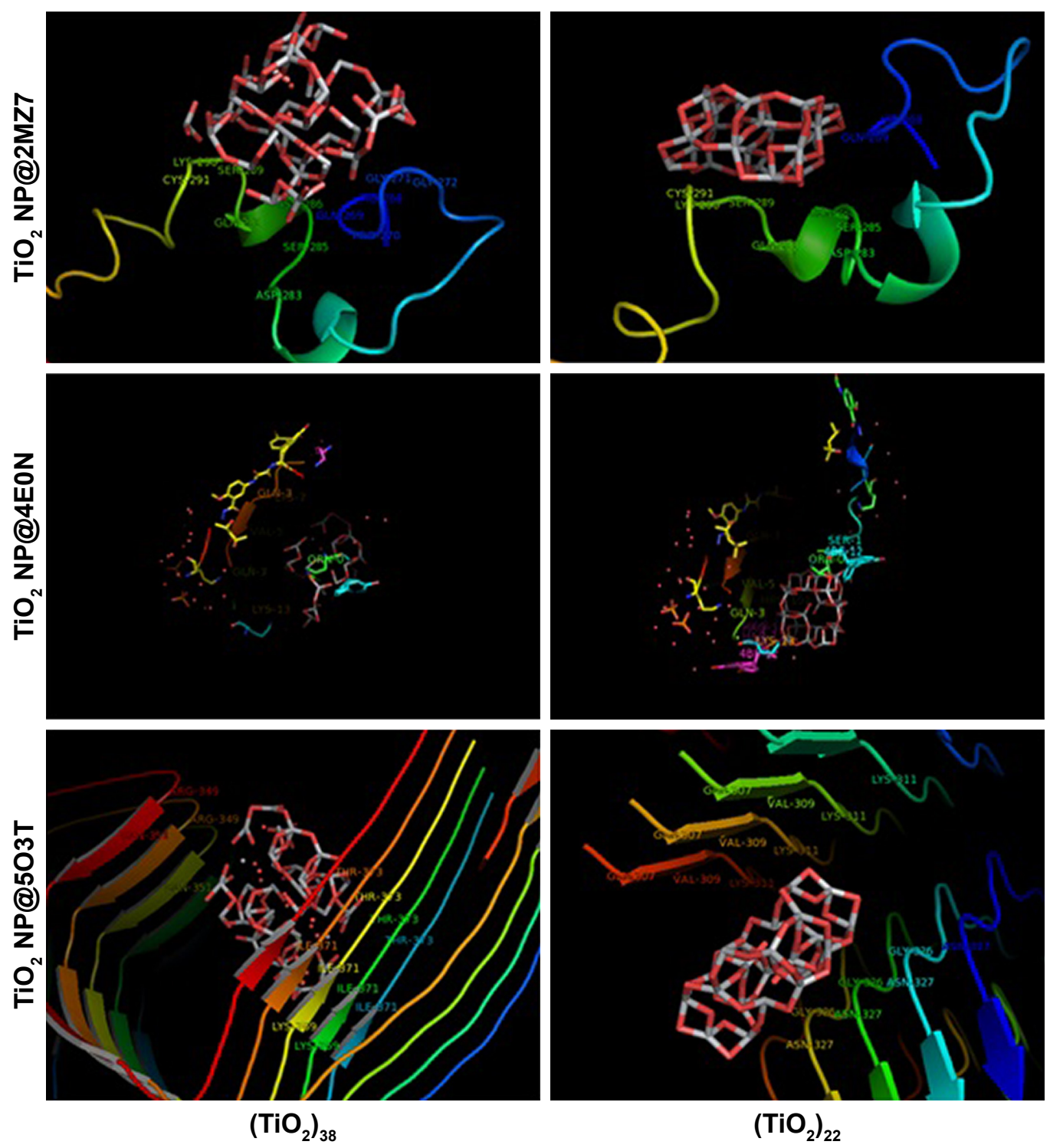

$\left(\mathrm{TiO}_{2}\right)_{22}$

Figure II The closest interacting residues of $\left(\mathrm{TiO}_{2}\right)_{22}$ and $\left(\mathrm{TiO}_{2}\right)_{38}$ clusters after interaction with tau segments.

Abbreviations: NPs, nanoparticles; $\mathrm{TiO}_{2}$, titanium dioxide.

\section{Quantification of apoptosis}

Flow cytometry analysis was also employed to quantify the induction of apoptosis by $\mathrm{TiO}_{2} \mathrm{NPs}$ and $\mathrm{TiO}_{2} \mathrm{NPs} / \mathrm{tau}$ samples. Figure 14 shows that $94 \%$ of the control cells are in the viable cells quadrant (Q1) (Figure 14A). However, incubation of cells with $100 \mu \mathrm{g} / \mathrm{mL}$ of $\mathrm{TiO}_{2} \mathrm{NPs}$ (Figure 14B) and $100 \mu \mathrm{g} / \mathrm{mL}$ of $\mathrm{TiO}_{2} \mathrm{NPs} /$ tau (Figure 14C) samples resulted in $55.66 \%(* * P<0.01)$ and $95.42 \%(* * P<0.01)$ apoptosis

Table 2 Docking results of $\left(\mathrm{TiO}_{2}\right)_{22}$ with tau segments

\begin{tabular}{l|l|l|l}
\hline NP & $\begin{array}{l}\text { PDB ID of } \\
\text { receptor }\end{array}$ & $\begin{array}{l}\text { Docking score } \\
\text { (E-value) }\end{array}$ & Residue interacted \\
\hline$\left(\mathrm{TiO}_{2}\right)_{22}$ & $2 \mathrm{MZ7}$ & -333.52 & Cys-29I, Lys-290, Ser-289, Gln-286, Gln-269, His-268 \\
$\left(\mathrm{TiO}_{2}\right)_{22}$ & $4 \mathrm{EON}$ & -364.70 & Ser-I, Gln-3, Lys-I3, Val-5 \\
$\left(\mathrm{TiO}_{2}\right)_{22}$ & $5 \mathrm{O} \mathrm{T}$ & -335.66 & $\begin{array}{l}\text { Gln-307.J, Gln-307.H, Gln-307.F, Val-309.J, Val-309.H, Val-309.F, Lys-3II.J, Lys-3II.H, } \\
\text { Lys-3II.F, Lys-3II.D, Asn-327.G, Gly-326.G, Asn-327.E, Gly-326.E, Asn-327.C, Asn-327.A }\end{array}$ \\
\hline
\end{tabular}

Abbreviations: NP, nanoparticle; PDB, Protein Data Bank; $\mathrm{TiO}_{2}$, titanium dioxide. 
Table 3 Docking results of $\left(\mathrm{TiO}_{2}\right)_{38}$ with tau segments

\begin{tabular}{|c|c|c|c|}
\hline NP & $\begin{array}{l}\text { PDB ID of } \\
\text { receptor }\end{array}$ & $\begin{array}{l}\text { Docking score } \\
\text { (E-value) }\end{array}$ & Residue interacted \\
\hline$\left(\mathrm{TiO}_{2}\right)_{38}$ & $2 M Z 7$ & -377.22 & $\begin{array}{l}\text { Pro-270, Gln-269, His-268, Gly-27I, Gly-272, Asp-283, Ser-285, Asn-286, Gln-288, } \\
\text { Ser-289, Lys-290, Cys-29I }\end{array}$ \\
\hline$\left(\mathrm{TiO}_{2}\right)_{38}$ & $4 \mathrm{EON}$ & -434.02 & Gln-3, Val-5, Lys-13, Lys-7 \\
\hline$\left(\mathrm{TiO}_{2}\right)_{38}$ & $503 \mathrm{~T}$ & -451.53 & $\begin{array}{l}\text { Arg-349.J, Arg-349.H, Gln-35I.J, Gln-35I.F, Lys-369.D, Ile-37I.H, Ile-37I.F, } \\
\text { Ile-37I.D, Ile-37I.B, Thr-373.B, Thr-373.H, Thr-373.F, Thr-373.D }\end{array}$ \\
\hline
\end{tabular}

Abbreviations: NP, nanoparticle; PDB, Protein Data Bank; $\mathrm{TiO}_{2}$, titanium dioxide.

induction in SH-SY5Y cells. It was also observed that the induction of apoptosis was more pronounced ( ${ }^{\#} P<0.01$ ) for $\mathrm{TiO}_{2} \mathrm{NPs} /$ tau than $\mathrm{TiO}_{2}$ NPs sample (Figure 14D). Therefore, it may be concluded that the $\mathrm{TiO}_{2} \mathrm{NPs}$ induced the formation of amorphous tau aggregates and these species can enhance the derived cytotoxicity of $\mathrm{TiO}_{2} \mathrm{NPs}$.

\section{Discussion}

Neurodegenerative diseases are characterized by tau aggregation. ${ }^{33}$ While several studies have focused on explaining the mechanisms of tau polymerization and a large body of data is available with information regarding the toxic effect of tau oligomers in the pathology of neurodegenerative diseases, ${ }^{34,35}$ studies exploring the aggregation of tau in the presence of NPs and induced cytotoxicity of NP/protein complex have been less numerous. Therefore, the aim of this study was to explore more detailed data regarding the structural changes of tau in the presence of $\mathrm{TiO}_{2} \mathrm{NPs}$ and the subsequent cytotoxicity of the $\mathrm{TiO}_{2} \mathrm{NP} /$ tau complex.

Intrinsic fluorescence spectroscopy revealed that $\mathrm{TiO}_{2}$ NPs quench the tyrosine fluorescence signal of protein and may form a complex with the protein. ANS fluorescence spectroscopy and CD spectroscopy investigations showed that the tertiary and secondary structure of tau was changed, respectively, in the presence of $\mathrm{TiO}_{2}$ NPs toward a more
A

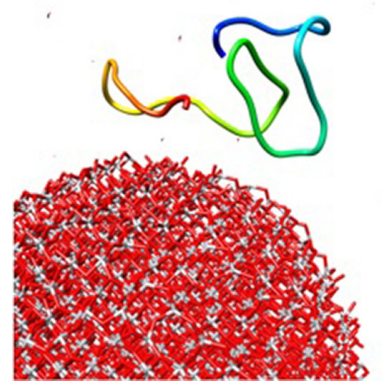

B

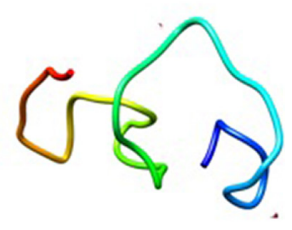

Figure I 2 The molecular dynamic study of $2 \mathrm{MZ7}$ segment in the presence (A) and absence (B) of $\mathrm{TiO}_{2}$ cluster after 300 ps evolution.

Abbreviation: $\mathrm{TiO}_{2}$, titanium dioxide. packed structure. UV-visible spectroscopy data indicated that increasing doses of $\mathrm{TiO}_{2} \mathrm{NPs}$ accelerate the formation of amorphous tau aggregates. We found that $\mathrm{TiO}_{2} \mathrm{NPs}$ strongly increase the formation of amorphous tau aggregates only after 2 minutes of incubation, suggesting that the NPs may induce an aggregation nucleus that appears early in the amyloid formation pathway. ThT fluorescence was almost constant after addition of increasing concentrations of $\mathrm{TiO}_{2}$ NPs which could be a reliable marker for the formation of amorphous aggregated structures. ${ }^{29}$ In the presence of $\mathrm{TiO}_{2}$ $\mathrm{NPs}$, tau aggregation was oriented toward a distinct aggregate species that shows no affinity for ThT.

It has been also reported that copolymer NPs, cerium oxide NPs, quantum dots, and carbon nanotubes may increase the probability of induction of an early nucleus for protein aggregation. ${ }^{36}$ The nucleation phase is strongly modulated by the physicochemical properties of NPs. NPs may change the structure of proteins and extend the formation of aggregated species. It was also reported that $\mathrm{A} \beta$ fibril formation increases in the presence of $\mathrm{TiO}_{2} \mathrm{NPs}^{37} \mathrm{NPs}$ due to their unique properties could shorten the lag phase, which is the

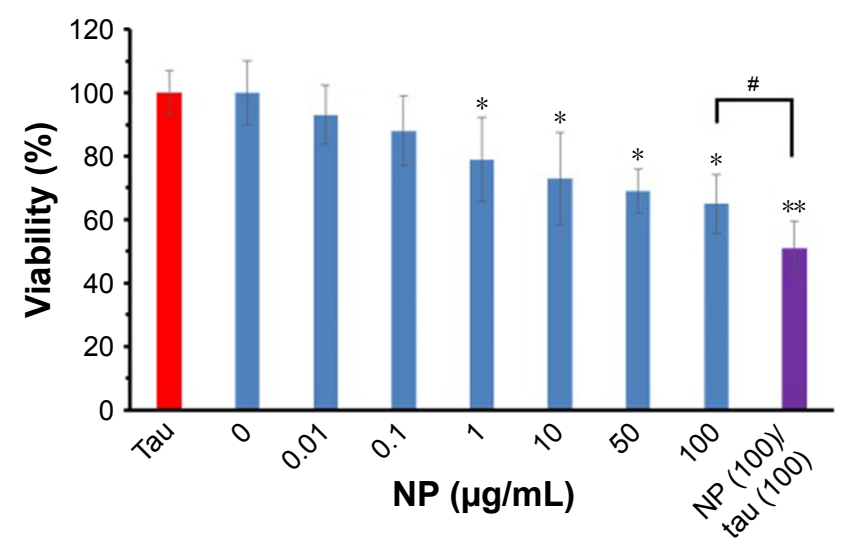

Figure 13 Effect of tau $(100 \mu \mathrm{g} / \mathrm{mL}), \mathrm{TiO}_{2} \mathrm{NPs}(0.0 \mathrm{I}-100 \mu \mathrm{g} / \mathrm{mL})$, and $\mathrm{TiO}_{2} \mathrm{NPs} / \mathrm{tau}$ complex $(100 \mu \mathrm{g} / \mathrm{mL} / 100 \mu \mathrm{g} / \mathrm{mL})$ on viability of SH-SY5Y cells.

Notes: Cell viability was studied using the MTT assay. Data are shown as mean \pm $\mathrm{SE}$ of three independent experiments. $* P<0.05$ and $* * P<0.01$ vs negative control group $\left(0 \mu \mathrm{g} / \mathrm{mL}\right.$ of $\left.\mathrm{TiO}_{2} \mathrm{NP}\right) .{ }^{\# P}<0.05$ vs $\mathrm{TiO}_{2} \mathrm{NP}\left(100 \mu \mathrm{g} / \mathrm{mL}\right.$ of $\left.\mathrm{TiO}_{2} \mathrm{NP}\right)$ group. Abbreviations: NPs, nanoparticles; $\mathrm{SE}$, standard error of mean; $\mathrm{TiO}_{2}$, titanium dioxide. 

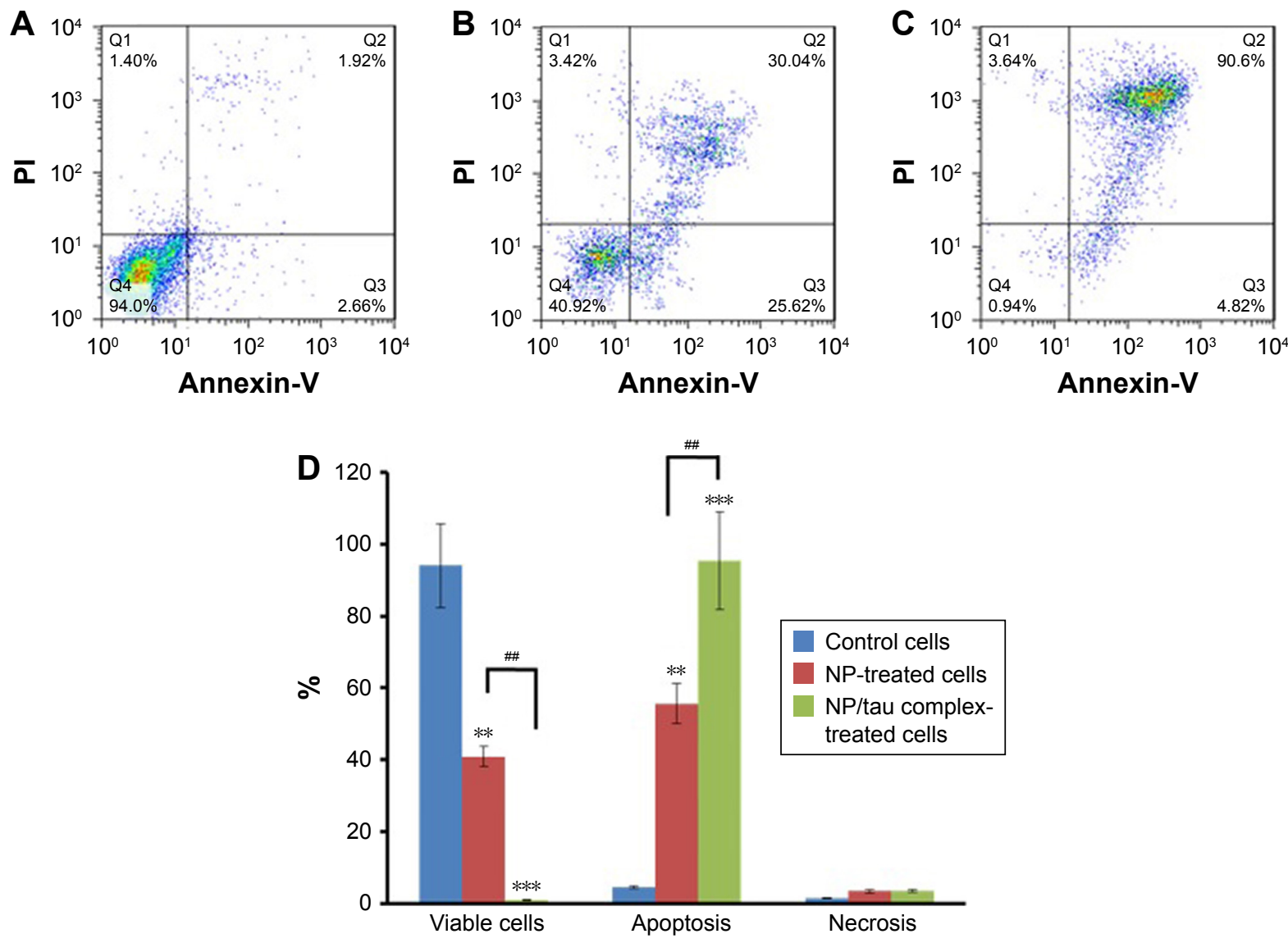

Figure 14 Probing the apoptosis induction of $\mathrm{TiO}_{2} \mathrm{NPs}(0 \mu \mathrm{g} / \mathrm{mL})(\mathbf{A}), \mathrm{TiO}_{2} \mathrm{NPs}(100 \mu \mathrm{g} / \mathrm{mL})\left(\right.$ B), and $\mathrm{TiO}_{2} \mathrm{NPs} / \mathrm{tau}$ complex $(100 \mu \mathrm{g} / \mathrm{mL} / \mathrm{l} 00 \mu \mathrm{g} / \mathrm{mL})(\mathbf{C})$ in SH-SY5Y cells by flow cytometry assay; the column graph represents the statistical analysis of apoptosis induction in SH-SY5Y cells by TiO ${ }_{2} \mathrm{NPs}$ (D).

Notes: Data are shown as mean $\pm \mathrm{SE}$ of three independent experiments. ${ }^{*} * \mathrm{P}<0.01$ and ${ }^{*} * \mathrm{P}<0.00 \mathrm{I}$ vs negative control group $\left(0 \mu \mathrm{g} / \mathrm{mL}\right.$ of $\left.\mathrm{TiO}_{2} \mathrm{NP}\right)$. ${ }^{\# P}<0.01$ vs $\mathrm{TiO} \mathrm{O}_{2} \mathrm{NP}$ $\left(100 \mu \mathrm{g} / \mathrm{mL}\right.$ of $\left.\mathrm{TiO}_{2} \mathrm{NP}\right)$ group.

Abbreviations: NPs, nanoparticles; PI, propidium iodide; $\mathrm{SE}$, standard error of mean; $\mathrm{TiO}_{2}$, titanium dioxide.

key path of aggregation. ${ }^{37}$ However, some conflicting results regarding NPs and aggregation have been reported. NPs have been investigated in several studies as a drug candidate that reduces the aggregation of proteins involved in neurodegenerative disorders. ${ }^{38-40}$ For example, an NP-chelator conjugate was developed as a therapeutic approach for Alzheimer disease to reduce the formation of fibril and neurotoxicity. ${ }^{38}$ Liao et al also reported that negatively charged gold NPs reduce the induction of amyloid $\beta$ fibrillization and decrease neurotoxicity. ${ }^{39}$ Mahmoudi et al showed that physiochemical features of superparamagnetic iron oxide NPs can change the amyloid $\beta$ fibrillation in solution. Concentration, surface groups, and diameter of NPs can provide a "dual" effect on protein fibrillation. ${ }^{40}$ Therefore, the impact of NP on protein aggregation or disaggregation should be well investigated.

Cellular assays revealed that the $\mathrm{TiO}_{2} \mathrm{NP} /$ tau sample is more toxic than free $\mathrm{TiO}_{2} \mathrm{NPs}$. As the NP-protein interaction results in denaturation of proteins, it is crucial to explore the NP-protein complex interaction with cells. Here, we showed that the $\mathrm{TiO}_{2}$ NPs folded the tertiary structure of tau which in turn increases the cytotoxicity of $\mathrm{TiO}_{2} \mathrm{NPs}$.

The formed hydrophobic patches of tau in the presence of $\mathrm{TiO}_{2} \mathrm{NPs}$ can result in increased cytotoxicity of the $\mathrm{TiO}_{2}$ $\mathrm{NPs} /$ tau complex compared to pure $\mathrm{TiO}_{2} \mathrm{NPs}$. Rapid corona formation and the structural changes of proteins are revealed to influence cell death at a fixed exposure time.

$\mathrm{TiO}_{2} \mathrm{NPs}^{41}$ and gold $\mathrm{NPs}^{42}$ were demonstrated to trigger structural changes of tubulin and serum albumin, respectively. It was hypothesized that the mechanism of cytotoxicity is the increased immunogenicity induced by exposing protein hydrophobic cores on their surface in a denatured conformation. ${ }^{41-43}$ For example, it was shown that the presence of some moieties on the surface of gold NPs caused unfolding of fibrinogen that, in turn, resulted in an interaction with the leukocyte receptor, thereby inducing inflammation. ${ }^{44}$

Disaggregation of proteins may result in mitigating the aggregated species of protein-induced cytotoxicity. For example, Meng et al revealed that polyphenols inhibit 
amyloid formation, disaggregate protein aggregation, and protect cells against amyloid polypeptide-induced cytotoxicity. ${ }^{45}$ Sheynis et al also reported that aggregation modulators can interfere with cellular interactions of aggregated species of proteins. ${ }^{46}$ Also, it was suggested that the surface charge, ${ }^{47} \mathrm{NP}$ distribution, ${ }^{48}$ adsorbed proteins, ${ }^{49}$ and physicochemical properties of $\mathrm{NPs}^{50}$ may affect the NP-induced cytotoxicity. Protein adsorption on the NP surface may influence all these features and result in increasing or decreasing the cytotoxicity of NPs.

\section{Conclusion}

Biomacromolecules like proteins can be denatured in the presence of NPs and subsequently may change the fate of NPs in biological systems. Since, protein corona modifies the NP surface, protein structural changes thus affecting the adverse effects of NPs. In this study, we showed that $\mathrm{TiO}_{2}$ led to the formation of hydrophilic interactions with $\mathrm{TiO}_{2} \mathrm{NPs}$ and altered the secondary and tertiary structure of the tau protein. These structural changes finally resulted in the formation of amorphous tau aggregates. Afterwards, it was shown that the conformational changes of tau enhance the derived cytotoxicity from $\mathrm{TiO}_{2}$ NPs. These data determined the adverse effects of NPs on protein structure and the role of the protein corona in NP-induced cytotoxicity. Therefore, this study can be used in the development of new approaches to modulate adsorbed proteins to more efficiently apply NPs for medical settings.

\section{Acknowledgment}

The financial support of Tehran Medical Sciences, Islamic Azad University, Tehran, Iran is greatly acknowledged.

\section{Disclosure}

The authors report no conflicts of interest in this work.

\section{References}

1. Tian X, Zhang L, Yang M, et al. Functional magnetic hybrid nanomaterials for biomedical diagnosis and treatment. Wiley Interdiscip Rev Nanomed Nanobiotechnol. 2018;10(1):e1476.

2. Smith BR, Gambhir SS. Nanomaterials for in vivo imaging. Chem Rev. 2017;117(3):901-986.

3. Mokhtarzadeh A, Alibakhshi A, Hashemi M, et al. Biodegradable nano-polymers as delivery vehicles for therapeutic small non-coding ribonucleic acids. J Control Release. 2017;245:116-126.

4. Nasrollahi SA, Hassanzade H, Moradi A, et al. Safety assessment of tretinoin loaded nano emulsion and nanostructured lipid carriers: a non-invasive trial on human volunteers. Curr Drug Deliv. 2017;14(4):575-580.

5. Hjorth R, Coutris C, Nguyen NHA, et al. Ecotoxicity testing and environmental risk assessment of iron nanomaterials for sub-surface remediation - Recommendations from the FP7 project NanoRem. Chemosphere. 2017;182:525-531.

6. Ma Z, Garrido-Maestu A, Lee C, et al. Comprehensive in vitro and in vivo risk assessments of chitosan microparticles using human epithelial cells and Caenorhabditis elegans. J Hazard Mater. 2018;341:248-256.
7. Laloux L, Polet M, Schneider YJ. Interaction between ingestedengineered nanomaterials and the gastrointestinal tract: in vitro toxicology aspects. Nanotechnology in Agriculture and Food Science. Weinheim: Wiley-VCH; 2017.

8. Kornberg T, Stueckle T, Antonini J, et al. Potential toxicity and underlying mechanisms associated with pulmonary exposure to iron oxide nanoparticles: conflicting literature and unclear risk. Nanomaterials. 2017;7(10):307.

9. Corbo C, Molinaro R, Parodi A, Toledano Furman NE, Salvatore F, Tasciotti E. The impact of nanoparticle protein corona on cytotoxicity, immunotoxicity and target drug delivery. Nanomedicine. 2016;11(1): 81-100.

10. Diederichs JE. Plasma protein adsorption patterns on liposomes: establishment of analytical procedure. Electrophoresis. 1996;17(3):607-611.

11. Monteiro-Riviere NA, Inman AO. Challenges for assessing carbon nanomaterial toxicity to the skin. Carbon. 2006;44(6):1070-1078.

12. Balbus JM, Maynard AD, Colvin VL, et al. Meeting report: hazard assessment for nanoparticles - report from an interdisciplinary workshop. Environ Health Perspect. 2007;115(11):1654-1659.

13. Monteiro-Riviere NA, Inman AO, Zhang LW. Limitations and relative utility of screening assays to assess engineered nanoparticle toxicity in a human cell line. Toxicol Appl Pharmacol. 2009;234(2):222-235.

14. Srivastava RK, Rahman Q, Kashyap MP, et al. Nano-titanium dioxide induces genotoxicity and apoptosis in human lung cancer cell line, A549. Hum Exp Toxicol. 2013;32(2):153-166.

15. Lagopati N, Kitsiou PV, Kontos AI, et al. Photo-induced treatment of breast epithelial cancer cells using nanostructured titanium dioxide solution. J Photochem Photobiol A Chem. 2010;214(2-3):215-223.

16. Wu X, Jiang $\mathrm{H}$, Zhou $\mathrm{Y}$, et al. Selective determination of drug resistant cancer cells on indium tin oxide electrode modified with nano titanium dioxide. Electrochem Commun. 2010;12(7):962-965.

17. Yin ZF, Wu L, Yang HG, Su YH, Fei Yin Z, Gui Yang H. Recent progress in biomedical applications of titanium dioxide. Phys Chem Chem Phys. 2013;15(14):4844-4858.

18. Kaviyarasu K, Geetha N, Kanimozhi K, et al. In vitro cytotoxicity effect and antibacterial performance of human lung epithelial cells A549 activity of Zinc oxide doped $\mathrm{TiO}_{2}$ nanocrystals: Investigation of bio-medical application by chemical method. Mater Sci Eng C Mater Biol Appl. 2017;74:325-333.

19. Calderón-Garcidueñas L, Reynoso-Robles R, Pérez-Guillé B, Mukherjee PS, Gónzalez-Maciel A. Combustion-derived nanoparticles, the neuroenteric system, cervical vagus, hyperphosphorylated alpha synuclein and tau in young Mexico City residents. Environ Res. 2017; 159:186-201.

20. González-Maciel A, Reynoso-Robles R, Torres-Jardón R, Mukherjee PS, Calderón-Garcidueñas L. Combustion-Derived nanoparticles in key brain target cells and organelles in young Urbanites: culprit hidden in plain sight in Alzheimer's disease development. $J$ Alzheimers Dis. 2017;59(1):189-208.

21. Maher BA, Ahmed IAM, Karloukovski V, et al. Magnetite pollution nanoparticles in the human brain. Proc Natl Acad Sci U S A. 2016; 113(39):10797-10801.

22. Auvinen S, Lahti M, Alatalo M. Unoccupied titanium $3 \mathrm{~d}$ states due to subcluster formation in stoichiometric $\mathrm{TiO}_{2}$ nanoparticles. Int J Quantum Chem. 2015;115(17):1175-1180.

23. Ritchie DW, Venkatraman V. Ultra-fast FFT protein docking on graphics processors. Bioinformatics. 2010;26(19):2398-2405.

24. Rappé AK, Casewit CJ, Colwell KS, Goddard WA, Skiff WM. UFF, a full periodic table force field for molecular mechanics and molecular dynamics simulations. J Am Chem Soc. 1992;114(25):10024-10035.

25. Abdolmajid E, Kharazi H, Chalaki M, et al. Titanium oxide nanoparticles fabrication, hemoglobin interaction, white blood cells cytotoxicity, and antibacterial studies. J Biomol Struct Dyn. 2018:1-38.

26. Rahmani S, Mogharizadeh L, Attar F, Rezayat SM, Mousavi SE, Falahati M. Probing the interaction of silver nanoparticles with tau protein and neuroblastoma cell line as nervous system models. J Biomol Struct Dyn. 2017;1(1):1-15. 
27. Zeinabad HA, Zarrabian A, Saboury AA, Alizadeh AM, Falahati M. Interaction of single and multi wall carbon nanotubes with the biological systems: Tau protein and PC12 cells as targets. Sci Rep. 2016;6(1): 26508.

28. Falahati M, Ma'mani L, Saboury AA, Shafiee A, Foroumadi A, Badiei AR. Aminopropyl-functionalized cubic Ia3d mesoporous silica nanoparticle as an efficient support for immobilization of superoxide dismutase. Biochim Biophys Acta. 2011;1814(9):1195-1202.

29. Mahdavimehr M, Meratan AA, Ghobeh M, Ghasemi A, Saboury AA, Nemat-Gorgani M. Inhibition of HEWL fibril formation by taxifolin: mechanism of action. PLoS One. 2017;12(11):e0187841.

30. Wang SS, Wen WS. Examining the influence of ultraviolet $\mathrm{C}$ irradiation on recombinant human $\gamma$ D-crystallin. Mol Vis. 2010;16:2777-2790.

31. Shokohi-Pour Z, Chiniforoshan H, Sabzalian MR, Esmaeili SA, Momtazi-Borojeni AA. Cobalt (II) complex with novel unsymmetrical tetradentate Schiff base (ON) ligand: in vitro cytotoxicity studies of complex, interaction with DNA/protein, molecular docking studies, and antibacterial activity. J Biomol Struct Dyn. 2018;36(2): 532-549.

32. Hunter NH, Bakula BC, Bruce CD. Molecular dynamics simulations of apo and holo forms of fatty acid binding protein 5 and cellular retinoic acid binding protein II reveal highly mobile protein, retinoic acid ligand, and water molecules. J Biomol Struct Dyn. 2018;36(7): 1893-1907.

33. Goedert M, Masuda-Suzukake M, Falcon B. Like prions: the propagation of aggregated tau and $\alpha$-synuclein in neurodegeneration. Brain. 2017;140(2):266-278.

34. Frenkel-Pinter M, Tal S, Scherzer-Attali R, et al. Cl-NQTrp alleviates tauopathy symptoms in a model organism through the inhibition of tau aggregation-engendered toxicity. Neurodegener Dis. 2017;17(2-3): 73-82.

35. Shrivastava AN, Aperia A, Melki R, Triller A. Physico-pathologic mechanisms involved in neurodegeneration: misfolded protein-plasma membrane interactions. Neuron. 2017;95(1):33-50.

36. Linse S, Cabaleiro-Lago C, Xue WF, et al. Nucleation of protein fibrillation by nanoparticles. Proc Natl Acad Sci U S A. 2007;104(21): 8691-8696.

37. Wh W, Sun X, Yp Y. Tio 2 NPS promote $\beta$-amyloid fibrillation in vitro. Biochem Biophys Res Commun. 2008;373(2):315-318.

38. Liu G, Men P, Kudo W, Perry G, Smith MA. Nanoparticle-chelator conjugates as inhibitors of amyloid-beta aggregation and neurotoxicity: a novel therapeutic approach for Alzheimer disease. Neurosci Lett. 2009;455(3):187-190.
39. Liao YH, Chang YJ, Yoshiike Y, Chang YC, Chen YR. Negatively charged gold nanoparticles inhibit Alzheimer's amyloid- $\beta$ fibrillization, induce fibril dissociation, and mitigate neurotoxicity. Small. 2012; 8(23):3631-3639.

40. Mahmoudi M, Quinlan-Pluck F, Monopoli MP, et al. Influence of the physiochemical properties of superparamagnetic iron oxide nanoparticles on amyloid $\beta$ protein fibrillation in solution. ACS Chem Neurosci. 2013;4(3):475-485.

41. Gheshlaghi ZN, Riazi GH, Ahmadian S, Ghafari M, Mahinpour R. Toxicity and interaction of titanium dioxide nanoparticles with microtubule protein. Acta Biochim Biophys Sin. 2008;40(9):777-782.

42. Wangoo N, Suri CR, Shekhawat G. Interaction of gold nanoparticles with protein: a spectroscopic study to monitor protein conformational changes. Appl Phys Lett. 2008;92(13):133104.

43. Nel AE, Mädler L, Velegol D, et al. Understanding biophysicochemical interactions at the nano-bio interface. Nat Mater. 2009;8(7):543-557.

44. Deng ZJ, Liang M, Monteiro M, Toth I, Minchin RF. Nanoparticleinduced unfolding of fibrinogen promotes Mac-1 receptor activation and inflammation. Nat Nanotechnol. 2011;6(1):39-44.

45. Meng F, Abedini A, Plesner A, Verchere CB, Raleigh DP. The flavanol (-)-epigallocatechin 3-gallate inhibits amyloid formation by islet amyloid polypeptide, disaggregates amyloid fibrils, and protects cultured cells against IAPP-induced toxicity. Biochemistry. 2010;49(37): 8127-8133.

46. Sheynis T, Friediger A, Xue WF, et al. Aggregation modulators interfere with membrane interactions of $\beta 2$-microglobulin fibrils. Biophys $J$. 2013;105(3):745-755.

47. Fröhlich E. The role of surface charge in cellular uptake and cytotoxicity of medical nanoparticles. Int J Nanomedicine. 2012;7:5577.

48. Aggarwal P, Hall JB, Mcleland CB, Dobrovolskaia MA, Mcneil SE. Nanoparticle interaction with plasma proteins as it relates to particle biodistribution, biocompatibility and therapeutic efficacy. Adv Drug Deliv Rev. 2009;61(6):428-437.

49. Zhu Y, Li W, Li Q, et al. Effects of serum proteins on intracellular uptake and cytotoxicity of carbon nanoparticles. Carbon. 2009;47(5): 1351-1358.

50. Rivera-Gil P, Jimenez de Aberasturi D, Wulf V, et al. The challenge to relate the physicochemical properties of colloidal nanoparticles to their cytotoxicity. Acc Chem Res. 2013;46(3):743-749.
International Journal of Nanomedicine

\section{Publish your work in this journal}

The International Journal of Nanomedicine is an international, peerreviewed journal focusing on the application of nanotechnology in diagnostics, therapeutics, and drug delivery systems throughout the biomedical field. This journal is indexed on PubMed Central, MedLine, CAS, SciSearch $®$, Current Contents $\AA /$ Clinical Medicine,

\section{Dovepress}

Journal Citation Reports/Science Edition, EMBase, Scopus and the Elsevier Bibliographic databases. The manuscript management system is completely online and includes a very quick and fair peer-review system, which is all easy to use. Visit http://www.dovepress.com/ testimonials.php to read real quotes from published authors. 